\title{
PECULIARITIES OF EXPRESSING THE APPREHENSIVE IN RUSSIAN
}

\author{
NADEZHDA ZORIKHINA NILSSON \\ University of Gothenburg
}

\section{A B S T RACT}

The present paper deals with different ways of expressing apprehension in Russian by the verbal constructions using the subordinating conjunctions как бы (не) and чтобы (не) and the $-\Omega(-1)$-subjunctive verb form or infinitive. The components of the constructions and the peculiarities of the synonymity of the conjunctions are examined in more detail. Special attention is given to the status of the negative particle $\mathrm{He}$. We argue that negation in the apprehensive does not lose its semantic nature but its manifestations are uncommon due to the assertion-suspending contexts it operates within.

\section{[1] INTRODUCTION}

Languages throughout the world are able to employ a variety of grammatical forms and structures to express a category that denotes apprehension or concern on the part of the speaker about some imminent undesirable event. This semantic category has been termed the apprehensive (Plungyan $(2004,17)$; Dobrushina (2006)). However, the Russian language does not possess any specialized means of expressing it, although its meaning can be conveyed by a number of linguistic forms. Among these, the most prominent position is held by a construction incorporating the subordinating conjunction как бы (не) ${ }^{1}$ (in case; lit. 'how would not') and an $-\Omega(-1)$-subjunctive verb form (1) or infinitive (2):
(1)
Как бы
она
не простуди-ла-сь!
how MOD:CNJ she:NOM NEG catch.a.cold:PF-CONJ(PRT).SG.F-REFL
'In case she caught/might/should/would catch a cold!'
(2) Как бы [только] не простуди-ть-ся!
how MOD:CNJ only:ADV NEG catch.a.cold:PF-INF-REFL

[1] The conjunction как бы (не) derives from the interrogative pronominal adverb как 'how' and the modal particle бы, which is genetically a form of the 2-3 pers. sg. aorist of the verb бытu 'be', which already in Old Russian was used as an auxiliary verb in the subjunctive analytical form (Gorshkova, Chaburgaev 1981, 317). Besides the combination "adverb + particle", Old Russian even had the conjunctions אakr (како) бы, какъ было, which expressed the goal of an action or condition (Slovar' russkogo jazyka XI-XVII, 7, 28-29). The question of the status of the negative particle $\mathrm{He}$ 'not' and its attachment to the conjunction is currently a thorny issue in Russian grammar, for which reason the particle He is enclosed in brackets in this paper. Our approach to this problem is expressed in section [4]. 
'In case [only] [I, we] catch a cold!'

Formally, this structure is a subordinate clause, which clearly by virtue of its vividly expressed semantics, has detached itself from the main clause and can be used independently. Cf. (1), (2) and (3):

a. Я боюсь, как бы она не

how MOD:CNJ she NEG

простудилась.

catch.a.cold:PF-CONJ(PRT).SG.F-REFL

I am afraid that she would/might catch a cold.

'I am anxious for her not to catch a cold.'

b. Я боюсь, как бы не простудиться

how MOD:CNJ NEG catch.a.cold:PF-INF-REFL

'I am anxious/afraid that I would/might catch a cold.'

However, it is more probable that the sentences under consideration have undergone a different process of development. Observations show that subordinate relations in old Russian were formed by combining a pair of sentences, where the function of the subordinate clause was usually assigned to a sentence, which had an indirect modality, i.e. a sentence expressing a question, a command or a wish (Lomtev 1956, 488). Thus, being independent in the narrative chain of sentences of the heterogeneous syntactic nature, the sentences with the adverbial construction как бы were drawn into a closer relationship with other sentences while their modal function attenuated. Therefore, these sentences which in modern Russian are perceived as fragments of complex sentences may actually, from a diachronic point of view, represent independent sentences. They did not become real subordinate clauses but instead managed to preserve a relative autonomy. ${ }^{2}$

This paper presents an analysis of the apprehensive construction with the conjunction как бы (не) in complex or simple sentences with an infinitive phrase, in both of which such a construction is often a dependent part (P1), occupying one of the valency positions of the main verb form or the verb phrase of the main part (P2). ${ }^{3}$ The dependent part communicates a possible situation, which, from the point of view of the speaker (or the subject of the main clause), is undesirable and in Russian can also be introduced by the conjunction чтобы (не) (in order not.... /so that ... not/that...). Cf.:

[2] This hypothesis needs verification that involves data derived from the history of the language.

[3] The structures under analysis are a variety of valency taxis constructions. For valency taxis please refer to: Khrakovskiy (2009). 
(4) Наши дамы по субботам домашних спектаклей не устраивали, боялись, как бы он не узнал... (А.Чехов - НКРЯ ${ }^{4}$ ).

Our ladies did not stage plays at home on a Saturday being afraid that he /could/might/would find out. (A. Chekhov - RNC)

(5) Как я боялась, чтобы не спросили из вежливости: «Как дела?» (Л. Гурченко - НКРЯ).

How I was afraid in case they could/might/would ask out of politeness, "How are things?" (L. Gurchenko - RNC)

As noted in "Russian Grammar" (RG, v. 2, 479), in the sentences undergoing analysis, the meaning of apprehension is expressed explicitly in the main part, which contains words denoting fear or concern (verbs such as бояться ' fear $^{25}$; onacaться 'be apprehensive'; пугаться 'be frightened'; страшиться 'be afraid of','be careful (not to)', etc. (see examples (4), (5), (6); or nouns such as боязнь 'fear'; cmpax 'worry'; опасение 'apprehension', etc. Example (7)):

(6) Других гостей здесь не боятся, а вас опасаются, чтобы вы Прасковье Ивановне чего-нибудь не пересказали (С. Аксаков - НКРЯ).

Other guests are not feared here, but with you they are careful so that you might/should/will not say anything to Praskovia Ivanovna. (S. Aksakov RNC)

(7) Женской прислуги он не держал из страха, чтобы о нем не думали дурно ... (А. Чехов - НКРЯ).

He never kept maidservants fearing/out of fear that they could/might/would think ill of him ... (A. Chekhov - RNC)

In traditional grammars of Russian the complex sentences under consideration are listed among sentences with object clauses. ${ }^{6}$ However, it should be noted that these clauses are not prototypical and they do not always express pure object relations as "that" clauses do. In addition to the "content" of fear emotion (бояться чего? 'fear of what'?), they also express the reason of the emotion (бояться почему? 'fear why'?), although to varying degrees. The syncretic semantics of such clauses can in some cases allow a peculiar "split" of the object (or valency expansion) at the syntactic level. Thus, in the example (6) the object position of the verb onaсаться 'be apprehensive' is in the main clause filled by the pronoun вы 'you' in the genitive while the existence of a second object is not completely forbidden. This phenomenon can be explained by the additional adverbial semantics of the subordinate clause. Here, in our opinion, we can speak about the transition case, in

[4] Hereinafter HКРЯ/RNC - Russian National Corpus.

[5] In the quotations the closest English equivalent is given. However, the translation may use synonyms.

[6] Cf. the Russian term «изъяснительное придаточное предложение» (GCLRL, 701-706; RG, 2, 473-479). 
which two roles - that of the argument and that of the sentential adjunct - are combined in one clause. As for example (7) the object semantics of the subordinate clause here coexists with the attributive.

The main part may also contain verbs denoting feelings and actions that accompany apprehension or are caused by it (беспокоиться 'worry'; волноваться 'be uneasy'; nредостерегать 'warn'; тревожиться 'be anxious') and words with the meaning of surveillance and supervision (присматривать 'watch'; караулить 'guard'; посматривать, поглядывать 'glance round', 'keep an eye (on)', etc.). Examples (8) and (9):

(8) З За эти годы я провел немало бессонных ночей, волнуясь, как бы его катер не утонул вместе с мотором (В. Маккавеев - НКРЯ).

All these years I spent a good many sleepless nights worrying in case his boat might/would sink//sank together with the motor. (V. Makkaveev - RNC)

(9) Ребята послали меня присмотреть, как бы чего не вышло (В. Рыбаков НКРЯ).

The guys sent me to watch in case something happened/could/might/would happen. (V. Rybakov - RNC)

In a more detailed analysis, it is necessary to consider the frequency of occurrence and the peculiarities of the use of the conjunctions in propositions containing all of the aforementioned semantic groups of verbs and nouns. Here, we will confine ourselves to complex sentences and infinitive clauses where the main clause predicate (P2) is expressed by the verb бояться 'fear'. This verb is pre-eminent as it is the most representative of all those in the groups considered, and examples with other verbs will be given in a few cases only. In the article we examine in greater detail the components of the constructions (section [2]) and the peculiarities of the synonymity of the conjunctions (section [3]). In the conclusion, the various viewpoints on the status of the negative particle $н$ with the conjunctions чтобы (не) and как бы (не) will be analyzed, while our approach to this problem (section [4]) will also be defined.

\section{[2] THE COMPONENTS OF THE CONSTRUCTION}

The dependent part of the propositions examined takes the form of a structure comprising the conjunction как бы ог чтобы, a finite $-\Omega(-1)$ verb form or an infinitive, as well as the particle $\mathrm{He}$. The infinitive is used when the subjects of the main and the dependent clauses are co-referent. A formal expression of the subject with the infinitive is possible but this is a very rare case and the subject then takes the dative case (10). 
(10) a. Я боюсь, чтобы мне не утратить и то, что хоть порою мне дается от неба (Н. Лесков - НКРЯ)

I fear that I might lose even that which, at times, is given to me by Heaven. (N. Leskov - RNC)

b. Рассказывали, что, когда Черчилля попросили прокомментировать сие событие, он якобы ответил так: «Я думал, что я умру от старости, но боюсь, как бы мне не умереть от смеха (М. Козаков - НКРЯ).

They say that when Churchill was asked to comment upon this event, he supposedly answered, "I thought that I would die of old age, but now I fear that I shall die laughing". (M. Kozakov - RNC)

It should be noted that the Russian language possesses a large number of infinitive constructions with the subject - the recipient of the situation expressed by the infinitive - in the dative. These infinitive constructions have a modal character. They can express (absence of) necessity, (im)possibility, directivity, and wish (Fortuin 2000, 237).

Among the modal infinitive constructions, constructions with negation and with the particle $6 u$, can also be found. As a rule, they function in speech as independent sentences and they are, indeed, semantically close to the constructions with как бы, which can also be used independently. Another common feature of both infinitive constructions is the fact that the infinitive has the form of the perfective aspect. Cf.:
a. Не отставай, не опоздать бы к обеду (Б. Пастернак, Посторонний). 'Come on, move, we don't want to be late for dinner (Fortuin ibid, 434).
b. Не отставай, как бы не опоздать к обеду.

The difference lies in the fact that in the complex sentences under analysis, the meaning of apprehension is expressed explicitly in the main clause by the verb бояться.

As for the structures with an $-\Omega(-1)$ verb form, the subjects of the subordinate and main clauses have as a rule different referents.

In the constructions under analysis, perfective verb forms are predominantly used, although the use of imperfective verbs is also possible (12). In the latter case, the majority of examples comprise predicates that include the imperfective verb быть (to be). Example (12-a):

(12) a. Он и слушать больше такого не мог, и боялся, чтобы проводы не были такими же торжественными, как встреча (Е. Чеповецкий - 
НКРЯ).

He could not tolerate hearing such things any more and feared that the send-off could/might/would be as grand as the welcome. (Ye. Chepoveckiy - RNC)

b. Скажи, что я улыбалась, боясь, чтобы он не рыдал (А. Щеглов - НКРЯ). Tell him that I was smiling out of fear that he could/might/would sob. (A. Shcheglov - RNC)

\section{[3] SYNONYMITY OF THE CONJUNCTIONS}

The question of the synonymity of the conjunctions чтобы (не) and как бы (не) deserves particular comment. If we examine the purely numerical correlation of these conjunctions in the propositions under analysis, then, as our calculations will show, there is no significant difference in their use in subordinates with a predicate expressed by a finite $-\Omega(-1)$ verb form. In the Russian National Corpus they show approximately the same frequency of use (see table 1 ). The infinitive clause with чтобы (не) is observed, however, just over 2.5 times less often.

\begin{tabular}{lcc}
\hline & как бы (не) & чтобы (не) \\
\hline Infinitive & 33 & 12 \\
$-\Omega$ verb form & 486 & 458 \\
Total number in RNC & 519 & 470 \\
\hline
\end{tabular}

TABLE 1: Frequency of occurrence in the RNC of the conjunctions kak by (ne) and čtoby (ne) in sentences with the verb bojat'sja (fear) as the predicate of the main clause

A more detailed analysis highlights the fact that in many instances of the use of чтобы (не) in the propositions under review are encountered in the literature of nineteenth or early twentieth centuries, while the conjunction как бы (не) predominates in the latter period. In the "Grammar of the Contemporary Literary Russian Language" (GCLRL, 705), the conjunction как бы (не) is described as an expressively coloured substitute for чтобы (не). In this paper we would like to specify that it appears that in the modern language, the conjunction чтобы (не) with the aforementioned meaning is going out of use. Let us cite several rare examples appearing in the RNC and belonging to late twentieth and early twenty-first centuries.

(13) a. Она тебя любит и боится, чтобы тебя не обманули (Е. Евтушенко (1999) - НКРЯ).

She loves you and is afraid that you could/might/would be fooled. (Ye. Yevtushenko (1999) - RNC) 
b. Агатов пропустил несколько абзацев, боясь, чтобы не напекло голову (Д. Гранин (1962) - НКРЯ).

Agatov left out several paragraphs for fear that his head could/might /would get scorched from being in the sun too long. (D. Granin (1962) - RNC)

c. Это мой сынишка поставил на окне светильник, боится, чтобы мать не заблудилась (Б. Шергин (1930-1960) - НКРЯ).

It was my son who left the lamp in the window; he was worried that his mother could/might/would get lost. (B. Shergin (1930-1960) - RNC)

The fact that the conjunction чтобы (не) belongs to those phenomena that are disappearing from the contemporary Russian language is also confirmed by the results of a survey of respondents. ${ }^{7}$ Hence, Russian native speakers practically never use the conjunction чтобы (не) in example (14-a) and prefer как бы (не) in example (14-b), remarking that чтобы (не) sounds rather unnatural there. Cf.:

a. Врачи боялись, как бы (??? чтобы) я не догадался (С. Алешин (2001) - НКРЯ).

The doctors were afraid in case/that I guessed/I could/might/would find out (S. Aleshin (2001) - RNC)

b. Я боялся, как бы (?'чтобы) ты не заболела после своих скитаний (С. Таранов (1999) - НКРЯ).

I was afraid in case/that you became/you could/might/would become ill after all your wanderings. (S. Taranov (1999) - RNC)

In contexts such as (14), the semantics of causation and purpose with regard to чтобы (не) clearly conflict with the expression of undifferentiated meaning of presumption and of the hypothetical nature of the event, for which reason the conjunction как бы (не) is preferred. As for the use of чтобы (не) with the infinitive, the latest contemporary example found in the RNC belongs to the early twentieth century:

(15) А дошедши, в многолюдном сборище я боялся, чтобы не потеряться от маменьки в большой толпе деревенских мужиков и баб (И. Репин (19121917) - НКРЯ).

And having arrived, amidst the crowded gathering, I was afraid of losing/that I could/might/would lose mama in the huge crowd of peasant men and women. (I. Repin (1912-1917) - RNC)

[7] We interrogated 10 respondents aged from twenty-two to fifty-five. The tendency noted requires further investigation, which should be based on a more detailed survey taking into account both different forms of the verb бояться (fear) and the presence of negation in the main clause. 
Note that the verb бояться (fear) may form a part of structures of greater complexity, where it governs the infinitive in the main part. $C f$. :

(16) a. Но домой возвращзаться боялся, чтобы (*как бы) не навлечь на близких свое невезение (П. Акимов (2000) - НКРЯ).

However, he was afraid to return home so as /in order not to (*in case he brought/he could/might/would) bring his bad luck upon his family. (P. Akimov (2000) - RNC)

b. Подолгу быть около Ольги Леонардовны мы боялись, чтобы ( ${ }^{*} \kappa a \kappa$ бы) не утомить ее... (С. Пилявская (2000) - НКРЯ).

We were afraid to stay so long by Olga Leonardovna so as/in order not to tire her. (*in case she got tired). (S. Pilyavskaya (2000) - RNC)

The presence of a dependent infinitive after the verb бояться (cf.: боялся возвращзаться (afraid to return) (16-a) and боялись быть (afraid to stay) (16-b)) emphasizes the meaning of causation and purpose in the dependent part introduced by the conjunction, and thus, in such constructions, which constitute a purpose clause, the conjunction чтобы (не) is the only possible one.

Consequently, in contemporary Russian, one can note a continuing tendency towards further functional semantic differentiation of the formal means that express the speaker's apprehension at the approach of some undesirable event. The structure that employs the conjunction чтобы (не) is rarely used in an apprehensive meaning, and, at the same time, it is going to lose one of its formal components, the infinitive. This, in its turn, has strengthened the position of the constructions with как бы (не), which thus acquire a more pronounced specialization.

\section{[4] NEGATION OR NOT?}

One of the most interesting peculiarities of the propositions under analysis is the obligatory use of the particle $\mathrm{He}$ (not) in the dependent part. It should be noted that the possibility of omitting не still existed in the nineteenth century.

...он боялся, чтобы она к нему подходила, ибо не хотел, чтобы она могла приметить его страдания... (В. А. Жуковский. Письмо к С. Л. Пушкину (1837) - НКРЯ).

...he was afraid that she would approach him, for he did not want her to notice that he was suffering... (V. A. Zhukovskiy. The letter to S. L. Pushkin (1837) - RNC)

Such a use is also noted in the paper by Mel'chuk \& Iordanskaja (1990), exclusively in the case of the verb бояться, when accompanied by the conjunction чтобы. The authors cite a possible example: 
(18) Мать боится, чтобы он ехал туда верхом

(Mel'chuk \& Iordanskaja 1990, 23).

Mother is afraid that he will go there on horseback.

In their general comments, however, they note that, "many speakers avoid the construction with čtoby altogether" (ibid).

Russian grammars present differing views on the status of the negative particle не and also its attachment to the conjunctions чтобы and как бы, and both issues still remain a matter for discussion.

According to one point of view, the particle $\mathrm{He}$ belongs to the conjunctions чтобы не and как бы не (RG, vol. 2, 479). As an integral part of the conjunction, it loses its meaning of negation (Shuvalova 1983, 92). As proof, the supporters of this theory frequently cite the synonymity of the propositions such as (19) and (20):

Мать боялась, как бы/чтобы дети не заболели.

Mother was anxious for the children not to get ill.

(20) Мать боялась, что дети заболеют.

Mother was afraid that the children would get ill.

According to a second point of view, found in earlier Russian grammars, in particular in the "Grammar of the Contemporary Literary Russian Language", the particle $\mathrm{He}$ does not become part of the conjunctions, and the propositions under analysis possess a "negative subordinate" (GCLRL, 705).

The existence of two opposite viewpoints in describing the same linguistic object is apparently not without reason. Research in recent years has significantly extended and deepened our understanding of negation and the mechanisms of its interaction with other language units. ${ }^{8}$ A certain compromise comprises a third point of view, according to which the negation present in the conjunctions $k a k$ бы, чтобы and пока (until) is syntactic (expletive negation) and not a semantic one (Brown \& Franks 1995). ${ }^{9}$ One of the proofs of this latter position is the use of

[8] See, for example, a short review of different approaches in the work of Bylinina (2003) and Partee (2004). For various types of negation, in particular, global negation in an assertion-suspending context, which comprises the conjunctions under analysis, see also the work by Paducheva (2005).

[9] See, however, the critical review of this viewpoint in Abels (2005). 
positive polarity items and the non-use of negative polarity items in such propositions. ${ }^{10}$ For example:

$$
\begin{aligned}
& \text { Я боюсь, [как бы *никто/кто-нибудь/*кто-либо/\#кто-то не пришел] }{ }^{11} \\
& \text { (example from Bylinina (2003)). } \\
& \text { I am afraid that anyone whosoever /anybody at all might/would come. }
\end{aligned}
$$

Thus, the use of the pronoun кто-нибудь (21) with a negation and the impossibility, according to E. Bylinina, of using the pronoun нuкmo in this example demonstrate that "semantically, it is not a negative sentence ('expletive negation')" (Bylinina 2003, ibid). ${ }^{12}$ Unfortunately, the author does not give any explanation to the use of the либо-pronoun in her example (21). Why is it so that only нибудь-indefinites, but not либо-indefinites occur with как быне and чтобыне? Are there any cases where in clauses with these conjunctions $\mathrm{Hu}$-pronouns possible? As it will be shown below in our material, all the aforementioned types of the pronouns are found.

Let us consider in more detail the question of the status of negation in constructions with the apprehensive and present our position. In our view, the context of the apprehensive construction is an example of the assertion-suspending context. ${ }^{13}$ It is well known that the infinitive and the subjunctive belong to linguistic means for the suspension of assertion. Such contexts express "a direct refusal to take responsibility for the contents of the proposition". (Paducheva 2005, 17). As E. Paducheva has demonstrated, non-specific, non-referential indefinite pronouns such as какой-нибудь are widely used in the assertion-suspending contexts (22-a) and are practically inadmissible in the indicative mode (22-b) (Paducheva 2005, ibid):

(22) a. Написал бы что-нибудь /Написать что-нибудь /Напиши что-нибудь Would you write anything/ To write anything/ Write anything

b. *она написала что-нибудь.

*She wrote anything.

[10] Negative polarity items, i.e., items demanding a sentential negation in Russian include, for example, negative pronouns, while indefinite pronouns with the particles -то,-нибудь are regarded as incompatible with negation. As for the pronouns with the particle-либо, they belong to the type with its own particular semantics and distribution and they had to be analysed separately. There are some sort of "irrealis" contexts that license -нибудь-words (imperative, future, modal (possibility, necessity)) while they do not license -либо-words. -Либо-words can even occur in negative contexts, for example, in the contexts with distant negation. For further discussion and analysis see, for example, the works of Pereltsvaig (2000) and Partee (2004).

[11] The \# symbol in Bylinina's example denotes the possibility of TO-pronouns in a sentence with negation, but located, according to the author, out of zone of its action. (Bylinina 2003, ibid).

[12] Note that a number of Russian native speakers find it possible to use a negative pronoun никто (nobody) in (21). See even our examples $(24-a, b, c)$. The author of the cited article herself makes later a cautious assumption of a possibility of a combined semantic-syntactic procedure of negation in these sentences.

[13] For details see: (Weinreich 1963). 
It should be mentioned that indefinite pronouns with the particle -нибудь are widely represented in the material that we are analyzing, e.g. (23):

(23) a. Боюсь, как бы ему что-нибудь не помешало: уж больно торопится (Ю. Азаров (2002) - НКРЯ).

I am afraid in case anything gets/might/should/would get in his way: he is in so much of a hurry. (Yu. Azarov (2002) - RNC)

b. Позднее Надя осторожно сказала мужу об этом: она боялась, как бы Леонид Иванович не написал такое еще кому-нибудь (В. Дудинцев (1956) - НКРЯ).

Later, Nadia cautiously mentioned this to her husband: she was afraid that Leonid Ivanovich might/should/would write the same thing to anyone else. (V. Dudincev (1956) - RNC)

c. Уходя, он всегда запирал ее на ключ в комнате, боясь, чтобы она не натворила какой-нибудь беды (Г. Газданов (1966) - НКРЯ).

Leaving the house, he always locked her in the room for fear that she might cause some trouble (G. Gazdanov (1966) - RNC)

However, examples are found, even though they are rare, of the use of negative pronouns and also pronouns with the particle -либo.

(24) a. Но я беспокоилась не за вещи: боялась, чтобы никто не влетел в раскаленные уголья на кухне (Д. Костенко. «Континент», 2006, №129).

But I was not worried about household things: I was afraid that somebody (lit. nobody) would run into the burning hot coals on the kitchen fire. (D. Kostenko. "Kontinent", 2006, N129)

b. Боялись - как бы ничего дурного со мной опять не случилось (Н. Джин (1980-1998) - НКРЯ).

They were afraid in case anything (lit. nothing) bad happened/might /should/would happen to me again (N. Dzhin (1980-1998) - RNC)

c. Телевизионных камер было много, как никогда. Смотрительницы волновались, чтобы никто ничего не повредил (Санкт-Петербургские ведомости, Вып. № 023, 10.02.2009).

There were so many television cameras, more than ever before. The attendants worried in case anyone (lit. noone) might/should/would damage anything (lit. nothing) (The Saint-Petersburg Times, No 023, 10.02.2009).

d. Он боялся, чтобы кто-нибудь не помешал ему, чтобы что-либо не прервало его состояния (К. Вагинов (1928) - НКРЯ).

He was afraid that somebody might/should/would impede him, in 
case anything might/should/would disturb his state of mind. (K. Vaginov (1928) - RNC)

The examples in group (24) clearly illustrate the fact that prohibition on the use of negative polarity items in the propositions under analysis is not absolute. We must therefore ask ourselves how to explain these facts and whether these propositions contain a semantic negation.

In order to explain the peculiarities of negation in the constructions with the apprehensive, it is interesting to compare these constructions with two similar linguistic phenomena, on the one hand, the expression of negation with the conjunction noka (till/until/before/while), and the construction of the preventive on the other.

\section{[4.1] The conjunction Poka (till/until/before/while)}

As it has been shown in earlier works, in particular (Barentsen 1979, 2011; Zorikhina Nilsson 2002), the conjunction noka enters in a rather complex relationship with negation and the verbal predicate of the subordinate part. The degree of cohesion of the entire structure depends in particular on the aspect and the lexical meaning of the verb incorporated in it, as well as on the type of the taxis relations between the situations in the main and the dependent parts. It is possible to distinguish three cases of the use of the particle $\mu$ in structures with the conjunction пока. In the first case, the particle не cannot be omitted, and this case is most vividly manifested in propositions where the action of the main clause is interrupted as a result of some sudden event. The perfective verb of the dependent part denotes an action without an inherent duration; as a rule, it is a momentary, instantaneous action.

(25) Мать его была слаба здоровьем, хозяйство совсем запустила, жила коекак... пока не утонула однажды в реке (В. Войнович).

His mother was of tender health, she neglected her household, let everything slide... until one day she drowned in the river. (V. Vojnovič)

Cf.: $\quad$ *...жила кое-как ... пока утонула однажды в реке.

*...let everything slide... while one day she drowned in the river.

In the second case, the omission of $\mathrm{He}$ changes the meaning of the subordinate clause into the opposite. Cf. (26-a) and (26-b):

(26) a. Смотри скорей, пока не погасло (lit. as long as it has not gone out). Hurry up and take a look, before it goes out.

b. Смотри скорей, пока погасло.

Hurry up and take a look, while it is out (as long as it is still out). ${ }^{14}$ 
In the third case, we could speak about the synonymity of subordinate clauses with and without $\mathrm{He}$ :
a. В поисках подарка все ювелирки города обошел, пока нашел что- то по-настоящему красивое [ср. пока не нашел] (Интернет). Looking for a gift I passed all jewelry stores before /until I found some- thing truly beautiful (Internet).
b. Я так половину города обошел, пока не нашел то, что искал [ср. по- ка нашел] (Интернет).
I passed half the city before I found what I was looking for (Internet).
c. Я прочитала инструкцию и выпила. Все равно пол ночи крути- лась, пока заснула! [ср. пока не заснула] (Интернет). I read the instructions and drank. I still tossed and turned half the night before I fell asleep (Internet).

In all the aforementioned cases, the conjunction nока retains its principal meaning: it denotes the limited duration of the situation in the main clause relative to that in the subordinate clause, while the particle $\mathrm{He}$, in our view, combines two functions. Firstly, it marks the "absence of action" in the dependent part against the background of the continuing action in the main clause. Thus in (25), logically, the action «не утонула» ('did not drown') could be interpreted as an action absent during the entire lifetime of the subject, whereas in (26) and (27), the situations expressed by the two predicates («смотри» ('take a look') and «не погасло»; ('did not go out'); «обошел» ('passed') and «не нател» ('did not find'); «крутилась» ('tossed and turned') and «не заснула» ('did not go to sleep')) co-exist on the temporal axis. In the latter case the particle realizes its prototypical function of negation. However, this function is often concealed by the communicative intentions of the speaker, who wishes to emphasize the change from one action to another and not the absence of some action against the background of another one. The second function of the particle $\mathrm{He}$ in such structures could be called a communicative or intentional one: this particle is used to mark the cessation of the action of the main part and the advent of a new event or condition.

Unlike the conjunction noкa, which, in contemporary Russian, has preserved its variability in combining with both the positive and the negative predications, the conjunctions чтобы and как бы, when used in the apprehensive, invariably demand the particle $\mu$ with the predicate. Note that the impossibility of omitting $\mu$ before the verb in such structures cannot serve, by itself, an argument in favor of the loss of the negative function of the particle. In relation to this, let us examine another construction where $\mathrm{He}$ is an indispensable part.

[14] Examples from the work of (Zorikhina Nilsson 2002, 84). See this article for further discussion. 


\section{[4.2] The preventive and the apprehensive}

One of the convincing facts that demonstrate that negation has not lost its meaning in the apprehensive is its comparison with the preventive. Semantically, these two structures are similar: in both cases they express the speakers' concern about some undesirable future event, but in the preventive, the speaker is actively trying to prevent possible consequences of the present situation by using the imperative form to address the listener, which is never observed in the case of the apprehensive. Cf.:
a. Смотри, не заболей!
Don't you get ill!
b. Я боюсь, как бы дочь не заболела.
I am anxious for my daughter not to get ill.
I am worried in case my daughter gets ill.

The preventive meaning is described quite well and in some detail in the linguistic literature (Khrakovskiy \& Volodin 2001; Birjulin 1994). Here, we shall present the basic semantic components of the situation with the preventive in example (28-a), in order to better compare it with the apprehensive construction:

1. At the moment $t^{1}$, situation $P^{1}$ occurs ( $X$ is in good health, not ill, $P^{1}=\neg P^{2}$ ).

2. Situation $P^{2}$ ( $X$ will be ill, will become ill).

3. The speaker expresses apprehension at a possible imminent situation $P^{2}$.

4. The speaker does not want the situation $P^{2}$ to occur ( $X$ wants «not $\left.P^{2} »\right)$.

5. The speaker warns of the possibility of $P^{2}$ ( $X$ will be ill, will become ill).

As we can see from the enumeration of the components, number 5 , which is expressed by the imperative of a perfective verb, is excluded from the semantics of the situation involving the apprehensive. This situation, however, includes element 4 , although it is in a rather weak form: the $-\Omega(-1)$-subjunctive form after $\kappa a k$ бы emphasizes the wish of the speaker (the agent of the narrative). The speaker (the agent) expresses the wish that situation $P^{2}$ should not occur.

The presence of the semantic negation in the apprehensive and, at the same time, its absence in the synonymous indicative structure (28-c) can be easily explained by the fact that in the indicative, the future form is used to only indicate the fact that the situation $P^{2}$ is possible. Cf. $(28-b)$ and (28-c):

b. Я боюсь, как бы дочь не заболела.

I am anxious for my daughter not to get ill.

'The speaker expresses concern about the possibility that situation 
$P^{2}$ may occur'.

'The speaker expresses the wish that the situation $P^{2}$ would not occur' (weak component of sense).

c. Я боюсь, что дочь заболеет.

I am afraid that my daughter will get ill.

'The speaker expresses concern about the possibility that situation $P^{2}$ may occur'.

The situation described in the complex sentences with the subordinate introduced by the conjunction umo (that) involves only the elements $(1,2,3)$, i.e. it is less varied semantically than the construction with the apprehensive involving the conjunctions чтобы (не) and как бы (не). Propositions with the conjunctions что and чтобы (не) or как бы (не) are synonymous, but the synonymity is not absolute and cannot serve as an argument for the absence of semantic negation in the apprehensive.

It is also interesting to note that in constructions with the preventive, as well as with the apprehensive, it is possible to use both indefinite and negative pronouns. cf.:
a. [Смотри], не заболей ничем! (4) ${ }^{15}$
Don't you come down with anything!
b. [Смотри], не заболей чем-нибудь! (96)
Don't you come down with something!

(30) a. Не задави никого! (518)

Don't you hit anyone!

b. Не задави кого-нибудь! (406)

Don't you hit someone!

The examples (29) and (30) testify to the fact that also in structures with the preventive it is possible to use both negative and indefinite pronouns. However, in the case of the preventive the presence of negation has never been denied on these grounds. In our view, semantic negation is present both in the preventive and the apprehensive constructions, but it manifests itself in a non-standard fashion, which is conditional on the fact that from assertion-suspending contexts, we can expect a nontrivial behavior by the language units.

[15] The figure in brackets shows the number of cases where the sentence was found using the Google search engine for a search undertaken on December 1, 2010. 


\section{[5] CONCLUSION}

In this paper, I have examined the meaning of apprehension and concern about some undersirable event in Russian expressed by the verbal constructions using subordinating conjunctions как бы (не) and чтобы (не) and - $\Omega(-1)$-subjunctive verb form or infinitive.

The complex sentences and infinitive clauses where the main clause predicate is expressed by the verb бояться 'fear' were invistigeted in greater detail.

As the study of the large corpus data has shown, the structure that employs the conjunction чтобы (не) is rarely used in an apprehensive meaning and it is on its way to disappear from the contemporary Russian language, particulary in the infinitive clause. Thus, the constructions with как бы (не) acquire a more pronounced specialization.

The paper discussed one of the most interesting peculiarities of the propositions under analysis, namely the obligatory use of the particle $\mathrm{He}$ (not) in the dependent part and the semantic puzzles of the negation which is expressed in it. I considered the context of the apprehensive construction as an example of the assertion-suspending context. Although - нuбydb-pronouns (positive polarity items) were widely represented in my material, the examples of the use of $\mathrm{Hu}$ pronouns (strong negative polarity items) and -либо-pronouns (weak negative polarity items) were found. These facts allowed me to argue that the negation in the apprehensive construction has some semantic function. Furthermore, the comparison with other constructions (complex sentences with the conjunction nока (не) and preventive constructions) strengthened the arguments confirming the existence of "uncommon" uses. The negative particle ne (not) in these contexts interacts with the words of different meaning and this interaction results in a non-standard behavior of many language units involved.

The proposed analyses of the apprehensive constructions with the verb 6oяmься 'fear' could be extended to other words denoting fear and concern, feelings and actions that accompany apprehension as well as to words with the meaning of surveillance and supervision.

\section{AKNOWLEDGEMENT}

I am grateful to Adrian Barentsen and my anonymous reviewer for their very thoughtful comments and useful suggestions on an earlier version of this paper. All remaining errors are, of course, my responsibility. None of the above necessarily agree with the views expressed.

\section{REFERENCES}

Abels, K. 2005. 'Expletive Negation' in Russian: A Conspiracy Theory. Journal of Slavic linguistics 13(1). 5-74. 
Barentsen, A. 1979. Nabljudenija za funkcionirovaniem sojuza poka. In Dutch Contributions to the Eighth International Congress of Slavists, 57-159. Lisse.

Barentsen, A. 2011. O sxodstvax i različijax v upotreblenii ograničitel'nyx vremennyx sojuzov v sovremennyx slavjanskix jazykax. Preprint. To be published in Zbornik Matice srpske za slavistiku.

Birjulin, L. 1994. Semantika i pragmatika russkogo imperativa. Slavica Helsingiensia 13.

Brown, S. \& S. Franks. 1995. Asymmetries in the scope of Russian negation. Journal of Slavic Linguistics 3. 239-287.

Bylinina, Je. 2003. O sintaksise otricanija v russkom jazyke: otricatel'nye mestoimenija i konstrukcija "ni x, ni y". http://www.dialog-21.ru/ Archive/2003/Bylinina.htm.

Dobrushina, N.R. 2006. Grammatičeskie formy i konstrukcii so značeniem opasenija i predostereženija. Voprosy jazykoznanija 2. 28-67.

Fortuin, E.L. 2000. Polysemy or monosemy: Interpretation of the imperative and the dative-infinitive construction in Russian. Amsterdam: Institute for Logic, Language and Computation, Amsterdam University dissertation.

GCLRL. 1970. Grammatika sovremennogo russkogo literaturnogo jazyka. Moskva: Nauka.

Khrakovskiy, V.S. 2009. Taksis: semantika, sintaksis, tipologija. Tipologija taksisnyx konstrukcij. 11-113. Moskva: Znak.

Khrakovskiy, V.S. \& A.P. Volodin. 2001. Semantika i tipologija imperativa. Russkij imperativ. Moskva: URSS.

Lomtev, T.P. 1956. Očerki po istoričeskomu sintaksisu russkogo jazyka. Moskva: MGU.

Mel'chuk, I. \& L. Iordanskaja. 1990. Semantics of Two Emotion Verbs in Russian: bojat'sja 'to be afraid' and nadejat'sja 'to hope'. Australian Journal of Linguistics 10(2). 305-357.

Paducheva, E.V. 2005. Ėffekty snjatoj utverditel'nosti: global'noe otricanie. Russkij jazyk $v$ naučnom osveščenii 2(10). 17-42.

Partee, Barbara H. 2004. Formal Semantics, Lecture 8. Negation, Monotonicity, and Negative Polarity Items. RGGU April 8. people.umass.edu/partee/ RGGU_2004/RGGU048a\%20no\%20codes.doc (15.05. 2011). 
Pereltsvaig, A. 2000. Monotonicity-based vs. veredicality-based approaches to negative polarity: evidence from Russian. In T.H. King \& I.A. Sekerina (eds.), Formal Approaches to Slavic Linguistics: The Philadelphia Meeting 1999, 328-346. Ann Arbor: Michigan Slavic Publications.

Plungyan, V.A. 2004. Predislovie. Irrealis i real'nost'. In Issledovanija po teorii grammatiki, vol. 3, 9-27. Moskva.

RG. 1980. Russkaja grammatika, vol. 2. Moskva: Nauka.

Shuvalova, S.A. 1983. Složnoe predloženie. Moskva: MGU.

Slovar' russkogo jazyka XI-XVII. 1980. Moskva: Nauka.

Weinreich, U. 1963. On the semantic structure of language. In J. Greenberg (ed.), Universals of Language, 114-171. Cambridge (Mass): MIT Press.

Zorikhina Nilsson, N. 2002. Ešče raz o semantike vyskazyvanij s sojuzom poka. Scando-Slavica (48). 81-102.

AUTHOR CONTACT INFORMATION

Nadezhda Zorikhina Nilsson

Institutionen för språk och litteraturer

Göteborgs universitet

Box 200, 40530 Göteborg

Sweden

nadja.zorikhina@slav.gu.se 